\title{
The restoration of some stretches of the Sarno River (Southern Italy): from canalized environment to fluvial corridor
}

\author{
M. G. Braioni ${ }^{1}$, M. C. Villani ${ }^{1}$, A. Braioni ${ }^{2}$, G. Salmoiraghi ${ }^{3}$, \\ A. Locascio ${ }^{3} \&$ G. Cannata ${ }^{4}$ \\ ${ }^{1}$ Department of Biology, Padova University, Italy \\ ${ }^{2}$ Architect, Italy \\ ${ }^{3}$ Department of Evolutionary Biology, Bologna University, Italy \\ ${ }^{4}$ Regional Basin Authority of the River Sarno, Italy
}

\begin{abstract}
The widespread urbanization of the corridor of the Sarno River has drastically modified the environment of this fluvial system. The aerial recognitions show that "the river continuum" was replaced by a continuum of town centres developed along the course of the Sarno River and its tributaries often on both banks. The urban and industrial building areas appear as a continuum and the agricultural areas show critical conditions because they are crossed by important infrastructures, such as motorways, superhighways and railways. Nevertheless, the environment is not without a proper and certified ecological value as the fluvial corridor is partly included in the SIC IT 8040021 Monti Picentini and in the Sarno River Regional Park. In order to present an effective set of planning, management and projecting proposals consistent with the present condition an integrated evaluation of the "river fluvial corridor" system in line with the EU 2000/60 Directive was carried out. The state of the art was analysed in detail within five stretches by applying the complex Indices and the Model for the integrated, multidisciplinary evaluations of the "River Sarno fluvial corridor" system. The results obtained have pointed out at various levels the environmental critical hazards, and the various scenarios for removing these critical impacts; the positive and negative actions are explained by the procedural/action abacus.
\end{abstract}

Keywords: river fluvial corridor system, integrated multidisciplinary evaluation model, ecological - landscape indices, procedural/action abacus, restoration. 


\section{Introduction}

The River Sarno-Solofrana fluvial corridor system is subject to recurrent flooding and extended droughts. The risk of a drastic reduction of the biodiversity and self-purifying capacity as well, as the loss of the historical, cultural and environmental identity of the fluvial landscape is very high. The system presents morphological and hydro-geological characteristics derived from the volcano Vesuvium: it is the north main gate to the Regional Park of the Picentini Mountains; it is a connection element of the Nature 2000 sites network with sites of historical archaeological and environmental relevance of the Campania Region, such as the Sorrento Peninsula and the Island of Capri [1-3]. In this context of strong co-existence of elements of Quality, Degradation and Risk a model of integrated evaluation has been applied with the purpose of defining the direction-actions-projects of management and planning suitable for taking into account all aspects of the river fluvial corridor system by following the EEC Directives 2000/60 [4], 92/43 [5], the Italian law 152/2006 and the European Landscape Convention [6].

\section{Area of study}

According to the classification in the system A of the Annex II of the WFD, the River Sarno - Solofrana Basin corresponds to the Ecoregion 3 (Italy, Corse, Malts); the typology size, which is based on the catchment area, is medium; the altitude typology is lowland for the River Sarno and mid altitude for the Solofrana tributary; the geology of the basin is calcareous-siliceous. All five stretches of the Upper Sarno-Solofrana fluvial corridor system that were taken into account present high flooding risk and are included in the general reserve and controlled area of the new River Sarno Park perimeter. Stretch 1, Lavorate, is located on one of the three spring branch of the lowland, cemented in the caught source. Along the intermittent Solofrana tributary the following stretches have been located: 2. Montoro S., 3. S. Pietro, 4. Mercato S.S., 5. Addolorata Nocera I. (Fig. 1). Stretch 2 (located $4 \mathrm{~km}$ downstream of the third Italian industrial pole of tanning) is represented by meander typology "mountainside terraced-cultivation and/or hardwood"; Stretch 3 is represented by the typology "urbanized plain bounded by the Salerno-Avellino motorway". The bed and banks of both maintain the hydraulic security typologies of the period of the Bourbon Kingdom. Stretch 4, Mercato S.S., represents a cultivated and urbanized plain in which the River Solofrana receives the waters of the Laura tributary, bends south, splits in two and reflows surrounding an agricultural area whose south portion has been transformed into a high discharge detection area. The banks are mainly cemented. The basin surface is $50 \mathrm{~km}^{2}$. Stretch 5 represents a $U$ valley: in the Addolorata locality, River Solofrana receives a canalized tributary, bends south and splits into River Casarsana and River Dei Corvi, which reflow into Nocera I., surrounding a large agricultural area in which the landscape characteristics are still visible and in which the construction 


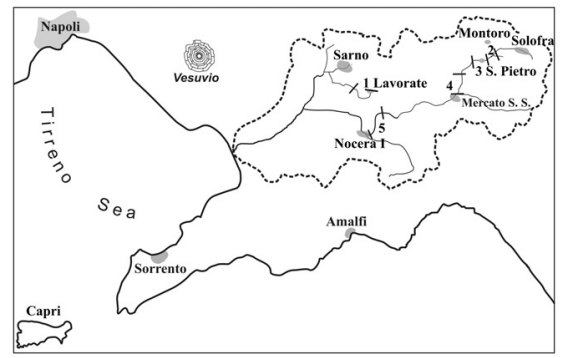

Figure 1: The Upper River Sarno-Solofrana fluvial corridor system.

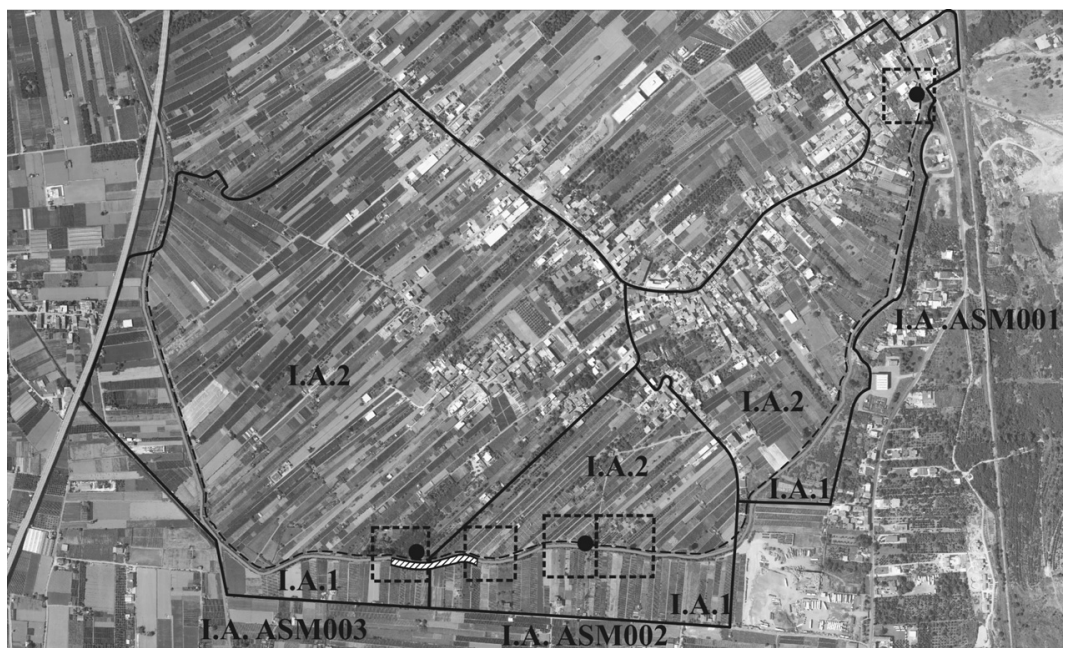

Figure 2: $\quad$ Stretch 1. The continuous line: the fluvial corridor area assessed by E.L.I.; the dotted line: main route and station point; the square area: riparian evaluated by W.S.I., B.S.I. (from Google, modified).

of a high discharge detection area is envisaged. There are numerous production activities and a waste water treatment plant. The banks are cemented and the basin surface is $212 \mathrm{~km}^{2}$.

\section{The method}

The model applied on the Upper Sarno-Solofrana fluvial corridor system is based on several key concepts and steps: close connection among the different types of inquiry since the set up of the study, in order to integrate at best the information starting from the different lexica and define the themes to be lined up from the different disciplines; gathering the necessary information with the objective of correlating them in an aggregated and disaggregated way; use of appropriate instruments to break down the territory complexity (environmentwise and landscape-wise) and re-combine it according to the purposes that have 
been defined and to identify in advance the possible scenarios in case one or more variables change; integration of the results to define a realistic view of the plan/project, consequently founding the planning of the river corridors on the evaluation of the quality/degradation/risk elements and hence on the ecologicallandscape sensibility.

\begin{tabular}{|c|c|}
\hline Survey phase & Results \\
\hline $\begin{array}{l}\text { Morphological, hydrological, hydraulic, territorial char- } \\
\text { acteristics; Aerial photos and thematic maps analysis; } \\
\text { Nutrients and pollution loads; Water, Biota and sediment } \\
\text { qualities; Inflow/Outflow; Hydrological balance; } \\
\text { Minimum discharge for sustainable water life; Climate }\end{array}$ & $\begin{array}{l}\text { Definition of the functional areas along the system Upper R. } \\
\text { Sarno -Solofrana -fluvial corridor; Delimitation of the Water } \\
\text { Bodies; Location of the sampling areas of the flora and } \\
\text { vegetation and for the assessment of the E.L.I., W.S.I., B.S.I. }\end{array}$ \\
\hline \multicolumn{2}{|l|}{ Experimental phase } \\
\hline $\begin{array}{l}\text { Survey on the field of the river - fluvial corridor; } \\
\text { Samplings of the flora and vegetation; the application of } \\
\text { the specific analysis forms of the E.L.I, W.S.I. and B.S.I. }\end{array}$ & $\begin{array}{l}\text { Assessment of the aggregated and disaggregated qualities of } \\
\text { the Indicators/Indices; Evaluation of the results acquired and } \\
\text { forecast; Compilation of the quality maps }\end{array}$ \\
\hline $\begin{array}{l}\text { Correlation } \\
\text { Indices/Indi }\end{array}$ & $\begin{array}{l}\text { f the results, of the aggregate and disaggregate qualities of the } \\
\text { cators of the compartments and components }\end{array}$ \\
\hline $\begin{array}{l}\text { Definition and filling of the procedural Abacus - Book of } \\
\text { indication at large-medium-small scale for the following Pla } \\
2000 \text { sites, Application of the Law Decree } 152 / 2006 \text {, Write o }\end{array}$ & $\begin{array}{l}\text { interventions, guidelines, norms, measures, contribution to } \\
\text { Water Safeguard, Landscape Safeguard, Nature Management } \\
\text { lan of a basin from hydro-geological perspective. }\end{array}$ \\
\hline
\end{tabular}

Figure 3: Model of integrated evaluation.

This setting in the experimental phase required the application of the complex indices (Environmental Landscape Index, E.L.I.; Wild State Index, W.S.I.; Buffer Strip Index, B.S.I.) and the elaboration of a procedural abacus to complete the other inquiries. The E.L.I. evaluates the environmental landscape quality of the fluvial corridor (expressed as the territory sensitivity to change, that is to say the capacity of the territory, or of a portion of it, to change without losing environmental value): this evaluation is made through a triple reading of the Elements/Variables present in a defined Inventoried Area (or I.A.) that is visible/can be read from the work station of the main route towards the river (or I.A.1) and "inwards" from the main route to the inland landscape (or I.A.2) [710] (Fig. 2). W.S.I. evaluates the potentiality of banks-riparian areas to support a high level of biodiversity on the base of the diversity, richness and complexity of the fluvial habitats. In the same area, the B.S.I. evaluates the potentiality to filter-buffer nutrients and pollutants based on the degree of complexity of the structures involved in the self-purifying fluvial processes [7-10]. The evaluations of the three Indices expressed in an aggregated and disaggregated way are complementary to those provided by the Index of Vegetation Naturalness [11], from the phytosociological analysis of vegetation [12], macrobenthos, waters, ground waters and sediments qualities and flow [13-15].

Finally, the procedural Abacus $[8,10]$ is a double enter grid containing the functional classification of the main types of actions following the analysis system correlated on their possible location in the space/time frame (Fig. 3). All norms/direction/intervention related to the topic defined by the grid is inserted in the appropriate cell so that the variable affected can be verified, any contradiction spotted and the most consistent actions or correction proposed. The abacus 
represents a modality of planning that shows its relevance when the forecast of an intervention on territories displaying particular complexity has to take into account a discrete number of systemic variables (i.e., environmental/landscape quality, areas that suffered human impacts and were abandoned thereafter, detractors, risks, etc.) and, at the same time, possible overlapping with other planning actions in use, proceeding thus through open plans and strategies that take into account the continuous intercourse among territory context/ecosystem functionality/ environmental/landscape relevance/norms.

\section{Results}

We include an example (Tab. 1) reporting some data of the aggregated and disaggregated quality of the E.L.I. and a synthetic description of the quality, degradation and risk elements detected in the 5 stretches under enquiry [12].

Table 1: $\quad$ Aggregate and disaggregate data of the E.L.I.

\begin{tabular}{|c|c|c|c|c|c|c|c|c|c|c|c|c|c|c|c|c|c|c|c|c|c|c|c|c|c|c|c|}
\hline & & & & & & & & & & & & & & & & & & & & & & & & & 01 & LSA & \\
\hline & & & & & & & ذ & 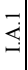 & ֻ & 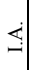 & 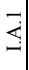 & ְ̦ & $\leftrightarrows$ & 青 & 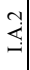 & 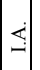 & - & 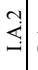 & & 妾 & & & & 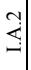 & & & \\
\hline Buildings & I & I & III & IV & III 1 & III & III & III & III & III & III & III & III & $\mathrm{I}$ & $\mathrm{I}$ & III & III 1 & III & III & III & III & I & I & III & $\mathrm{V}$ & V & \\
\hline$\overline{2 . R}$ & $\mathrm{~V}$ & $\mathrm{~V}$ & $\mathrm{~V}$ & II & II & II & I & I & II & $\mathrm{I}$ & $\mathrm{I}$ & II & $\mathrm{I}$ & $\mathrm{I}$ & $\mathrm{I}$ & I & \begin{tabular}{l|l}
$\mathrm{I}$ & \\
\end{tabular} & II & II & $\mathrm{I}$ & $\mathrm{V}$ & II & II & $\mathrm{V}$ & $\mathrm{V}$ & $\mathrm{V}$ & \\
\hline $3 . \mathrm{V}$ & III & II & III & III & II I 1 & V & $\mathrm{I}$ & I & $\mathrm{I}$ & $\mathrm{I}$ & . & $\mathrm{I}$ & III & III & III & II & III 1 & III & I & $\mathrm{I}$ & III & III & III 1 & IV & IV & IV & 111 \\
\hline $4 . \mathrm{W}$ & I & I & III & $\mathrm{I}$ & $\mathrm{I}$ & II & III & III & III & III & III & III & IV & IV & III & III & III $\mathrm{I}$ & III I I & III & III & III & $\mathrm{I}$ & \begin{tabular}{l|lll}
$\mathrm{I}$ & $\mathrm{I}$ \\
\end{tabular} & IV & $\mathrm{I}$ & $\mathrm{I}$ & \\
\hline 5. Detractors/Attractors & I & , & $\mathrm{I}$ & III & II & II & $\mathrm{I}$ & $\mathrm{I}$ & II & $\mathrm{V}$ & $\mathrm{V}$ & \begin{tabular}{|l|}
$\mathrm{I}$ \\
\end{tabular} & III & & IV & III & IV $1 \mathrm{I}$ & III & $\mathrm{V}$ & IV & $\mathrm{V}$ & $\mathrm{V}$ & $\mathrm{I}$ & $\mathrm{V}$ & III & III & t \\
\hline 6. View & & I & $\mathrm{I}$ & & I & I & & II & I & & II & II & & & III & & \begin{tabular}{l|l} 
II & 1 \\
\end{tabular} & III & & II & II & & II & II & & II & 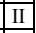 \\
\hline & & & & & & & & & & & & & & & II & & & & & & & & & & & III & t \\
\hline
\end{tabular}

Stretch 1 - Lavorate

The environmental-landscape quality of the river corridor, the wild state and buffer quality of the banks and riparian areas is respectively medium, scarce, bad in ASM001 (city centre of Lavorate, cached source, cemented bed). In ASM002 the disaggregated evaluation of the ELI shows again elements of deterioration: the back of the buildings oriented towards the main street of the city centre, a general disorder of the buildings, the crumbling structure of the aqueduct. The few historical buildings are abandoned; the city centre is tiny; the viability (farm and inter-farm roads and non asphalted parking) is not intrusive; the recreational activity is good (small canoes). The view, composed by high upward and downward slopes of the cultivated land and by hardwood mountainsides, shows only one element of degradation: the sight of a quarry. Many elements improve the quality of this stretch: a) long and narrow plots of land, interrupted by a narrow drainage ditch with vegetation each with two or three lots, mark the agricultural partition of the Samnite period (Paestum archaeological Museum); b) the relevant natural woody, grassy and bushy vegetation, the reed grove together with fruit and vine yards; c) the spring brooks with riparian vegetation; d) narrow open ditches network with riparian vegetation placed amid the cultures. Pleasant sounds, smooth colour variations and mosaic cultures increase the agreeability of the area. In ASM003 the quality improves due to the increase of the natural vegetation and a wetland grown into the bed notwithstanding the presence of the town waste. The view, excellent, shows a partly flat morphology. 
We can find Callitriche stagnalis one of the guide species of the Habitat of the Directive 92/43 cod 3260 "Water courses of plain to mountain levels with the Ranunculion fluitantis and Callitricho-Batrachion vegetation" inventoried downstream. The inflow from spring brooks and from a leak in the aqueduct, the whole lower water network in a continuum with the river wetland form a capillary ecological network able to sustain a high biodiversity and to contribute to the self purifying capacity of the stretch: the civil waste discharge is currently lower than the lowland stream one.

Stretch 2 Montoro S.

The environmental-landscape quality is always good. In the I.A. (Inventoried Area) SOLAV01 we can find rural courts, hydraulic building with historical value. The quality of the vegetation elements is always excellent: presence of woods, relevant woody mass and lone trees, vegetable gardens, fruit yards and uncultivated land. The crumbling structures serving the rural activities are visible only from the inside (I.A. 2) and reduce the disaggregated quality of the Group of Detractor/Attractor Elements. Where there is a direct visibility the view is good: the surrounding landscape is mainly cultivated and vegetated, the morphology of the land is composed by upward and downward slopes; the view is excellent inwards for the presence of a landmark (a sanctuary plunged in the mountainside). The Wilde State quality is always good. The cultivations on the terraced riparian areas and the viability are irrelevant. The small weirs dating to the Bourbons favour the stability of the riverbed and the upstream movements of the potential aquatic fauna, the formation of small bedrocks and the colonisation of the riverbed by the vegetation. This is confirmed by the presence of the Habitat cod. 3270 "Rivers with muddy banks with Chenopodion rubri p.p. and Bidention p.p. vegetation", of Annex I of the 92/43 Directive. The artificial banks with un-cemented cliffs made by big and deep steps allow the natural growing of the grassy vegetation. Occasionally, the native woody vegetation stretches without interruption on the mountainsides. Nevertheless, the disaggregated quality of some Sub-indices shows the unsuitability of the stretch to an increase of human presence. The sediments polluted by Chrome and Cadmium [3] and the irrelevant or scarce buffer-filter capacity confirm the vulnerability of the stretch already in the current conditions (with the exception of an area corresponding to the woody front). In I.A. SOLAV02, the ELI shows similarities with the neighbouring area; nevertheless, the presence/visibility of a disposal site towards the river reduces the quality of the Detractor/Attractor elements in I.A. and I.A.1. The view is good; the landmark is no more visible. The wild state and buffer-filter quality decrease only in the disposal site area.

Stretch 3 S. Pietro - Montoro I.

In I.A. SOLAV03 the city centre and the historically valuable hydraulic buildings contribute to the increase of the environmental-landscape quality which though shows elements of degradation: high presence of industrial buildings even if scarcely visible towards the river. The visibility/detection of the bank roads and parking is low inwards. The vegetal elements (relevant lone trees and rows, small cultivated areas and wild areas) are visible only inwards. The 
surrounding landscape is not always visible due to the presence of buildings. In SOLAV04 the city centre and the historical value of hydraulic infrastructures and buildings affect more the disaggregated qualities than the overall one. The reed grove is present/not detectable. The view is good towards the river due to the increase of wild state of the surrounding landscape. In SOLAV05, downstream the city centre of S. Pietro, the environmental-landscape quality improves for the presence/detection of great woody masses along the river. The buildings do not show quality elements. The presence/visibility of the highway and other detractors such as stinks and noises of the traffic reduce the quality inwards. The view is good, the visibility is filtered by the woody mass barrier, the visible landscape is mainly cultivated and vegetated, the land slopes a little towards the watercourse and hugely inwards. In SOLAV04 we can find the Habitat 3270 "Rivers with muddy banks with Chenopodion rubri p.p. and Bidention p.p. vegetation", inserted in the list of the Annex 1 of the 92/43 Directive in the riverbed [12]. The wild state and buffer-filter quality is medium/scarce/dreadful in the whole stretch due to the urbanization of the riparian areas. It improves only in the steep vegetated mountainside. The inadequate self-purifying potentiality of the stretch is confirmed in S. Pietro by the water quality assessed with the pollution level described through chemical parameters (LIM), by the dreadful state of the environment (SACA), by the levels of Chrome in the sediments and water, by the scarce quality of the Biotic Index IBE and through the water load trend mainly determined by the wastewaters [13-15].

\section{Stretch 4 Mercato S.S.}

The different evaluations (aggregated and disaggregated) of the environmentallandscape quality in SOLSA01 are determined by the presence/ detection/ invisibility of the few farm and inter-farm roads, few parking, hydraulic buildings, rural courts of historical value, urban concentration and few industrial buildings. The two Habitats Nature 2000 (code 3270 and 3260) also inventoried in ASM001, SOLAV01, SOLAV03 can be found in the riverbed of the Laura tributary. The scarce buffer-filter capacity in the agricultural area shows how any change in the current cultural mosaic would engender the vanishing of landscape valuable elements and a further increasing of pollutants [12].

Stretch 5 - Addolorata - Nocera I.

The quality elements occurring in SOLSA02 and SOLSA03 are mainly detectable towards the rivers course (I.A.1): in SOLSA02 historical buildings (rural houses, the Church of the Addolorata), structures of connection between the banks with historical value, limited presence of viability infrastructures, abundance of water elements partly covered by riparian vegetation, undetectable detractors such as few rubbish heaps and active quarries, visibility of cultures mosaic. In SOLSA03, deterioration elements consist of intrusive industrial buildings and the wastewater treatment plant, the strong presence of viability and low quality infrastructures, the wastewater treatment noise and the bad smell coming from waste disposals and landfills. Few quality elements are the R. Dei Corvi and its narrow drainage ditches with riparian vegetation, mixed with the 
mosaic of cultures still preserving the historical setting. In both areas the view is good: in the second the surrounding landscape is mainly cultivated and rich of vegetation, with medium-high level slopes, in the first it is also built and presents woody mountainsides. The wild state worsens due to highly cemented and banks and riparian areas. Only evergreen hygrophyla, grass, nitrophyla, occasionally Phragmites, succeed in colonizing small portions of banks and little bedrocks. The lack of appropriate morpho-hydrological and vegetation structures reduces drastically the buffer-filter quality of banks and riparian areas as well [12].

\subsection{Procedural abacus}

The procedural abacus has been elaborated to complete the integrated evaluation of the results coming from the different disciplines involved in the study (quoted herewith as referees) [13-15].

We implemented the classification of the main types of intervention that can positively or negative affect the components of the System Upper Sarno Solofrana conceived as environment, ecosystem, nature, landscape territory. In each cell, defined by the grid, a norm/direction/intervention/positive-negative action related to the topic, as reported an example in cell E2 (Tab. 2, 3).

Table 2: $\quad$ The procedural abacus.

\begin{tabular}{|c|c|c|c|c|c|c|c|c|c|c|}
\hline \multicolumn{11}{|c|}{ Functional classification of the main types of actions following the analysis system } \\
\hline \multirow{8}{*}{ 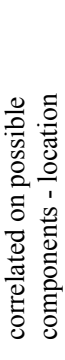 } & & & 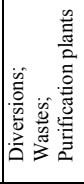 & 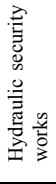 & 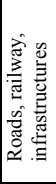 & 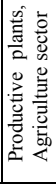 & 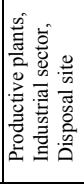 & 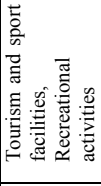 & 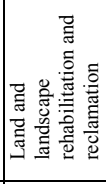 & 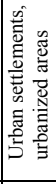 \\
\hline & & & 1 & 2 & 3 & 4 & 5 & 6 & 7 & 8 \\
\hline & A & Water & A1 & $\mathrm{A} 2$ & $\mathrm{~A} 3$ & A4 & A5 & A6 & A7 & A8 \\
\hline & $\mathrm{B}$ & Bed & B1 & B2 & B3 & B4 & B5 & B6 & B7 & B8 \\
\hline & $\mathrm{C}$ & Biota & $\mathrm{C} 1$ & $\mathrm{C} 2$ & $\mathrm{C} 3$ & $\mathrm{C} 4$ & $\mathrm{C} 5$ & C6 & $\mathrm{C} 7$ & C8 \\
\hline & $\mathrm{D}$ & Banks - Riparian Areas & D1 & D2 & D3 & D4 & D5 & D6 & D7 & D8 \\
\hline & E & Fluvial corridor & E1 & E2 & E3 & E4 & E5 & E6 & E7 & E8 \\
\hline & $\mathrm{F}$ & View & F1 & F2 & F3 & F4 & F5 & F6 & F7 & F7 \\
\hline
\end{tabular}

Table 3: An example.

\begin{tabular}{|c|c|c|}
\hline & E2: Positive actions & E2 Negative actions \\
\hline 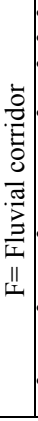 & $\begin{array}{l}\text { - To preserve and exploit the terraced mountainside } \\
\text { - To preserve and exploit the Hydraulic connectivity } \\
\text { - To safeguard or restore the riparian ecotones connectivity } \\
\text { of the whole watershed } \\
\text { - To identify the most effective location of the high discharge } \\
\text { detection area considering all aspects: hydrological, } \\
\text { hydraulic safety, the landscape characteristics and the soil } \\
\text { use for different modalities of fruition, as far as they are } \\
\text { sustainable } \\
\text { - Set up management plans for a sustainable, multiple fruition } \\
\text { of the extant high discharge detection areas, in order to } \\
\text { integrate nature, landscape and environment (see also E7). } \\
\text { - Carry out intervention of preservative maintenance of all } \\
\text { human crafts carrying historical value even minor ones } \\
\text { (such as hydraulic works). } \\
\text { - Flank these interventions with environmental education and } \\
\text { sharing with the population }\end{array}$ & $\begin{array}{l}\text { - Do not alter the outflow which does not respect the } \\
\text { minimum discharge for sustainable water life in periods } \\
\text { of drought, thus insulating stretches of riparian } \\
\text { hygrophilous vegetation. } \\
\text { - Build high discharge detection area, without riparian } \\
\text { native vegetation, thus unconnected to the ecological } \\
\text { fluvial corridor. Such an action would produce an } \\
\text { immediate and net interruption of the longitudinal } \\
\text { continuum. } \\
\text { - Build hydraulic security works (dams, weirs, banks, etc.) } \\
\text { with siding support of relevant dimensions by materials } \\
\text { which do not allow the seeding or the re-colonisation by } \\
\text { the native vegetation. Such an action would create a net } \\
\text { interruption of the viability of the river corridor. } \\
\text { - Rebuild historical buildings with materials and } \\
\text { modalities altering the historical-architectural character } \\
\text { of the place. }\end{array}$ \\
\hline
\end{tabular}




\section{Discussion and conclusions}

From the integrated evaluation of all the results we draw the conclusions and guidelines summarized below.

The insertion of the whole System Upper Sarno - Solofrana - fluvial corridor in the new perimeter of the Regional Park of the River Sarno confirms that it is an element of connection of the Nature 2000 sites network with the archaeological, historical- landscape - environmental of the Campania region due to the presence of Habitats Nature 2000, of high quality species and vegetation, of a good wild state quality, of a landscape-environmental quality of the fluvial corridor presenting highly valuable historical and landscape elements. It has thus to be included in the registry of the protected areas (according to the Law Decree152/2006 and the EEC Directive 60/2000) (4) with the purpose of reaching a good ecological state in 2015 . Nonetheless, the sediments are loaded of heavy metals; the water biota of the Solofrana tributary, naturally fragile as all intermittent water courses can't accomplish its self-purifying function due to the "water quantity" factor: in the periods of draught the flow is almost absent for the high exploitation of the water tables, in the periods of medium flood it is quickly conveyed between the hard-set and linear bank guard to avoid spate.

Urban, civil and industrial waste coming or not from purifying plant with different functionality and the first foul flush represent the constant matrix in which the biota should develop.

In this context three fundamental aspects of a process of safeguard, enhancement, ecological, landscape, environmental, economical restoration can be summarized in the location and modalities by which 1. wastewaters are transformed into waters matching the required quality standards, 2 . the river accomplishes its depuration, 3 . high discharge detection areas are built to protect from the hydraulic risk.

This way, the objectives reported below are reached:

- improve the quality of the water coming from the different types of dumping to use it for all purposes (irrigation, drinking, etc,);

- allow a sustainable use of the different water qualities which should stay separated until they reach an excellent level;

- enhance the landscape elements such as they evolved historically in the agricultural territory;

- allow a diversified recreational fruition, tailored to the different social and economical realities;

- design high discharge detection areas in line with the above mentioned objectives by a) re-naturalization interventions which take into account all the ecological, naturalistic, environmental and landscape aspects, b) the use of public and private funds, c) the organisation of the sharing by the different stakeholders.

These objectives come from some thoughts drawn from the perception of the territory and related to others regarding the system river-territory:

A. The territory included in the fluvial corridor, even though often transformed by inappropriate uses, still shows the changes it has been submitted 
to along the decades, that is to say the stratifications relevant in a restoration process. That's why, in spite of the unpleasantness cause by the overall spoilage, there is nothing there like the annoyance caused by featureless places, the feeling of estrangement and alienation. This is true especially if the environment/ landscape is observed according to a medium territory scale, e.g., the stretch downstream the town centre of Lavorate, or at the bridge of the Addolorata church. If a small scale (i.e., a single point of view) is taken in to account, instead, the situations are very different and vary from very high quality to total deterioration. The same if the wide territory is observed according to a large scale (e.g., examining an aerial photo): a widespread presence of buildings that unstructured the places. At a medium scale, instead, the past is so well settled in all its phases that even inappropriate human interventions have not erased it, such as the agricultural partition of the Samnite period (before the Roman domination) with long and narrow plots of land enclosed by small stones, interrupted by narrow drainage ditch with vegetation each two or three lots. The insertion of the big industrial areas is always difficult, as well as of the excavation areas and the parcelling of the suburbs, that are featureless interventions, all the same for typology and composition. For these last, the interventions are aimed at mitigate the impact on the environmental landscape.

B. Wastewaters of any type (civil or industrial) are a resource for the System Upper Sarno-Solofrana that cannot be renounced as they are the only ones that could guarantee the minimum discharge rate for a sustainable water life and the longitudinal continuity of the river system. The drainage of all civil water and their optimal purifying treatment are thus to be hoped for. In case the complete biological treatment process isn't optimized yet, the conveyance in the River Sarno - Solofrana of mid treated and first foul flush waters is the smaller threat. The scattered houses and urban agglomerates up to 2,000 inhabitants-equivalent would have to be equipped with primary mini-plant followed by wetlands systems to contribute to the flow capacity of River Sarno and of its tributary Solofrana. It is also useful not to renounce even wastewater from productive activities, but in these cases it is necessary to predispose for the single industrial activities a careful verification of the processes and of the risk of toxic pollutant inlet and consequently, to set up guidelines and more rigid norms. Downstream town centres where high discharge detection areas and/or where hydraulic interventions finalized to flood retaining are already envisaged, it will be necessary to foresee interventions that safeguard/restore the naturalistic ecological - landscaped characteristics of the water course in which the output flow, always present, would increase the awaited purification processes. Still it will be useful to retain foul flush with multiple and suitable high discharge detection area, those that contain also the optional output flow of the upstream depuration plants, to make sediments deposit that it is equivalent to withhold the greater polluted loads and to attain that in times of drought these settings can be also to support for the discharges.

From the above we are able to assume that the landscape/environment can be restored, working both on the small and on the medium scale, checking that the planning to large scale is not set against the recovery choices; this means, in 
other words, that one can start from plan scale making sure though that the urban and general planning choices are not in contrast. It is necessary to operate in this territory with the modalities of the "propositional restoration", i.e., to recover the evolutionary passages of the territory that are still visible and to link to them future intervention of requalification. In this way it is possible "to impose" the acknowledgement of the history, both natural and human, highlighting the stratifications. At the same time, shapes and structures can be contextualized in order to make the new uses sustainable. For example, high discharge detection area projects usually propose massive interventions of reforestation that, even if appropriate from the naturalistic point of view, are less coherent with the recovery of the historical landscape. Therefore, it is necessary to put on the table not only the topics related to the requalification of the wild state, but also those of the territory in its complex, including the landscape, keeping in mind that the European Landscape Convention integrates the two terms, "landscape" and "environment".

As an example, in stretch 5. Addolorata - Nocera inferiore, in which the Samnite historical landscape it is still present between River Casarsano and River Dei Corvi, the envisaged high discharge detection area project could be based on the topics mentioned here below (to be verified with the information supplied from the experts of the various disciplines).

1. Convey all the water, both natural and waste in the two water courses, verifying their different quality.

2. Supply the scattered houses, all the industrial activities, etc with waste water treatment technique using wet pool and wetland facilities.

3. Maintain all that is still "natural" (cane-brake).

4. Intervene with re-plantation and restoration at least on one bank, increasing both river beds, where possible, also in the urbanized areas.

5. Carry out one or more wetland on the side of the present riverbed, after the waste water plant.

6. Maintain the rural reticulum increasing the number of narrow drainage ditches with riparian vegetation to use as buffer zones in normal situation and as small "high discharge detection area" in the period of high flow.

7. Build a zone of regeneration (constructed wetland) at the end of the area and upstream the inhabited centre and use it as a place of recreation and as an additional high discharge detection area in the event of great flood [12].

\section{Acknowledgement}

This paper relies on study that was financed by the Regional Basin Authority of the River Sarno P.O.R. Campania 2000-2006 - misura 1.9 azione c.

\section{References}

[1] Autorità di Bacino del Fiume Sarno, Piano stralcio di bacino per l'assetto idrogeologico, Delibera Comitato Istituzionale n. 11 del 10/05/2002, 2002. 
[2] Regione Campania, Proposta di Piano Territoriale Regionale, Assessorato all’Urbanistica, Tutela Beni Paesaggistici Ambientali e Culturali, 2004.

[3] P.C.M._C.D.S.E.S.E.A. del Bacino del Sarno, Caratterizzazione dei sedimenti per la messa in sicurezza dell'alveo del F. Sarno, 2005.

[4] E.C., Directive 2000/60 establishing a framework for Community action in the field of water policy, 2000.

[5] E.E.C., Directive 92/43/ on the conservation of natural Habitat and its wild fauna and flora, 1992.

[6] Paour, F. \& Hitier, P., Recommendation 40 on draft European Landscape Convention, Council of Europe, 1998.

[7] Braioni, M.G., Bracco, F., Cisotto, P., Ghirelli, L., Villani, M.C., Braioni, A., Girelli, L., Masconale, M., Campeol, G., and Salmoiraghi, G., The biological - ecological and environmental landscape indices and procedures in the planning and sustainable management of the riverine areas: The case of the study of the river Dese and the river Adige. New Trends in Water and Environmental Engineering for Safety and Life, eds. U. Maione, B. Majone Lehto \& R. Monti, Balkema: Rotterdam, pp. 97-110, 2000.

[8] Braioni, M.G., Braioni A., Salmoiraghi G., Integrating ecological and hydrological issues into urban planning in the Adige river fluvial corridor, Italy (chapter 9.5). Aquatic Habitats in Sustainable Urban Water Management. Science, Policy and Practice, eds. I. Wagner, J. Marsalek and P. Breil, Urban Water Series - UNESCO - IHP vol.4, pp. 176-186, 2008.

[9] Braioni M.G., Braioni A., Salmoiraghi G., Gli Indici complessi WSI, BSI, ELI. Strumenti per il monitoraggio integrato e per il governo dei corridoi fluviali. Manuale di applicazione, QVA Strumenti e applicazioni n.6. Associazione Analisti Ambientali, Milano, pp 1-241(CD-ROM), 2008.

[10] Braioni M.G., Braioni A., Salmoiraghi G, Valutazione integrata del sistema fiume - corridoio fluviale mediante Indici ambientali e paesaggistici: $i$ sai studio del sistema Adige e Cordevole. Associazione Analisti Ambientali, Milano, QVA Studi n. 2, pp. 1-163.

[11] Pizzolotto R., Brandmayr P., An index evacuate landscape conservation state based on land-use pattern analysis and GIS. COENOSES, 11:37-44

[12] Braioni M.G., Braioni A., Locascio A., Salmoiraghi G., Villani MC., Predisposizione ed applicazione di un modello di valutazione integrata applicata al Sistema F. Alto Sarno - Solofrana - corridoio fluviale, Report to Autorità di Bacino del Sarno.

[13] Celico P.B. \& Habetswallner G., 2008. Monitoraggio qualitativo dei corpi idrici sotterranei compresi nell'area del Parco dei Monti Picentini. Basin Authority of the River Sarno

[14] Della Gatta M. \& D’Alterio D., 2008. Sintesi attività pluviometrica. Report to Basin Authority of the River Sarno

[15] Giugni M., 2008. Acque superficiali, Report to Basin Authority of the River Sarno 